\title{
Local climate, circulation and surface-energy balance of an Antarctic blue-ice area
}

\author{
R. Bintanja ANd M. R. VAN DEN BROEKe \\ Institute for Marine and Atmospheric Research, Utrecht University, 3584 CC Utrecht, The Netherlands
}

\begin{abstract}
Results of measurements performed on and around an Antarctic blue-ice lield are presented in this paper. The measurements were carried out in a valley of Heimefrontfjella, Dronning Maud Land, during a 2 month field season in the austral summer of 1992-93. A simple model is used to evaluate the surface-energy balance from measured meteorological quantities. The large differences in the surfaceenergy-balance valucs between snow and blue ice are mainly caused by differences in albedo, surfacc roughness, thcrmal conductivity and short-wave radiation extinction coefficient. Taking into account uncertainties in the calculations, it appears that the calculated sublimation rates over ice and snow do not differ much.

Furthermore, typical circulation patterns are described. The large continental-scalc katabatic flow is forced by radiative cooling of the surface (night-lime) and the mesoscale horizontal tempcrature gradient (daytime). The latter penetrates to the surface due to cnhanced mixing in an unstable stratified boundary layer. At night, shallow katabatic layers form along local fall lincs. On some occasions the large-scale katabatic winds decrease through the presence of a high-pressure system in the Weddell Sea and a local circulation can develop inside the valley.
\end{abstract}

\section{INTRODUCTION}

Blue-ice areas are, together with the dry valleys and some coastal regions, the only regions in Antarctica where the surface mass balance is negative. Since they are located on the leeward sides of mountain ridges or nunataks, they cover only a small part of Antarctica. The principal causes for their existence are: (1) low accumulation rates due to reduced snow-drift divergence in the wind shadow of mountains and surface smoothness, and (2) high ablation rates through sublimation (Orheim and Lucchitta, 1990). Bluc-ice areas have been observed in various mountainous regions in Antaretica (Schytt, 1961; Van Autenboer, 1964; Takahashi and others, 1988 ).

As part of the SWEDARP (Swedish Antarctic Research Program expedition to Antarctica, the authors stayed at the Swedish research station Svea $\left(74^{\circ} 35^{\prime} \mathrm{S}, 11^{\circ}\right.$ $13^{\prime} \mathrm{W}, 1250 \mathrm{~m}$ a.s.l.) from 23 December 1992 until 12 February 1993. Svea is located in a U-shaped, northwest southeast oriented valley called Scharffenbergbotnen (Fig. 1). Inside this valley a large blue-ice area $(2 \times$ $5 \mathrm{~km}^{2}$ ) is located. Scharffenbergbotnen is located in Heimefrontfjella, a northeast--southwest orientated mountain range that reaches a maximum height of approximately $2500 \mathrm{~m}$. During the 7 week measuring period, detailed observations of the metcorological conditions in and around the valley were carried out.

The purpose of the present study is to reveal differences in energy balance and sublimation rates between the blue-ice area and the surrounding snowfields. Furthermore, typical flow types and boundarylayer profiles are discussed. Since changes in the blue-ice area's extent are possibly related to climate change Orheim and Lucchitta, 1990), this study can be seen as a first step towards understanding the complex relation between local climate and blue-ice area extent.

\section{INSTRUMENTATION AND LOCATION OF MEASURING SITES}

In the vicinity of this blue-icc arca, meteorological quantities and surface-energy fluxes vary on a spatial scale of $1-5 \mathrm{~km}$. Therefore, measurements were carried out on seven sites in and around Scharffenbergbotnen within an area of $3 \times 18 \mathrm{~km}^{2}$ (Fig. 1, lower panel). Site 2 is located on blue ice at the southeasternmost part of the valley where the sublimation rates are at a maximum (Jonsson, 1992). Site 3 is situated near the northwest entrance of the valley on a snow ridge dividing the two major blue-ice fields inside the valley. Both sites 4 and 5 are situated outside the valley and are assumed to represent conditions typical for the plateau Ritscherflya. Site 1 should represent conditions for the higher plateau Pionerflaket. Two additional measuring sites (6 and 7) are situated on smaller bluc-ice fields on the western side of the valley.

At all sites masts were placed containing sensors for wind direction, wind speed, temperature ventilated), 


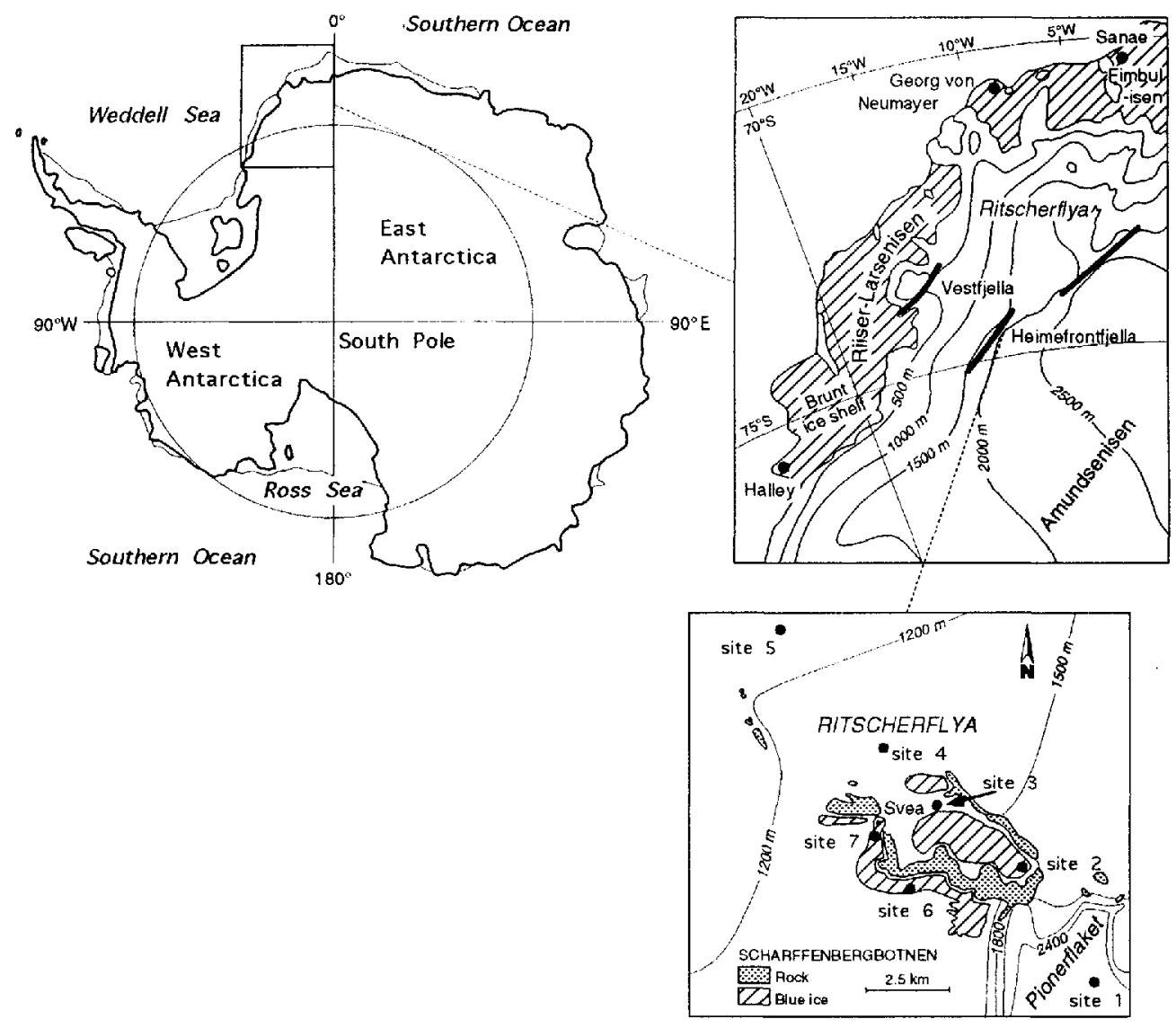

Fig. 1. Map showing the location of Heimefrontjella in Antarctica. The measuring sites are shown in the lower panel.

relative humidity (ventilated; only at sites 2,3 and 7 ), short-wave incoming and reflected radiation (sites $1,2,3$, $\bar{j}$ and 7 ), and total downward and upward radiation (sites 2 and 3). 'lemperature, humidity and wind-specd mcasurements were carried out at two or three heights 6 , 2 and $0.5 \mathrm{~m}$ ). At site 3 , snow temperatures were taken at five levels $(5,10,20,40$ and $80 \mathrm{~cm}$ depth). The sampling frequency of all sensors was $2 \mathrm{~min}$. Data were transmitted about every hour to the computer at Svea where they were stored. This allowed on-line graphical display of the data with the advantage of good insight into on-going physical processes. Some electronic problems werc encountered, probably related to drifting snow and low temperatures, causing some gaps in the data sets of sites 1 and 5 . The accuracy of the temperature, relativehumidity, wind-speed and wind-direction sensors are $0.2^{\circ} \mathrm{C}, 3 \%, 0.2 \mathrm{~ms}^{1}$ and 4 , respectively. The components of short-wave and all-wave radiation are accurate to 2 and $3 \mathrm{Wm}^{2}$, respectively.

'To study vertical profiles in the atmospheric boundary layer, cablc-balloon soundings were carried out near Svea up to a height of approximately $2250 \mathrm{~m}$. A tethersonde connected to the balloon measured wind speed, wind direction, temperature, relative humidity and pressure. Soundings were undertaken regularly (every $6 \mathrm{~h}$ ) when wind specd did not exceed $10 \mathrm{~ms}$ '. On nine selected days, soundings were taken every $3 \mathrm{~h}$.

Synoptic observations were also made during the measuring period. Every $3 \mathrm{~h}$, cloud lype and cloud amount were observed. For more details concerning the equipment and data-acquisition routine we refer to Bintanja and others (1993).

\section{METEOROLOGICAL CONDITIONS}

The daily mean meteorological parameters measured at site 3 are shown in Figurc 2. A slight cooling trend can be detected, indicating that the summer period is cnding. Periods of bad weather passed through, characterized by high winds from castcrly directions and large amounts of low cloud and occasionally precipitation. These periods are clearly associated with cyclonic activity near the coast, when humid air is advected inland. However, most of the time fair weather, characterized by light winds and small amounts of cloud, occurred. During these periods, a local circulation could develop within the valley with occasionally, westerly winds. Outside the valley (site 5) this local circulation could hardly be recognized.

The average cloud amount is 3.1 octas (low clouds 0.9 , middle clouds 1.2 and high clouds 1.0). During periods of fair weather, cumulus clouds were sometimes observed, indicating boundary-layer convection.

The mean and cxtreme data measured at sites 2, 3, 4 and 5 are given in Table 1. Since the elevation differences between the sites are less than $100 \mathrm{~m}$, the higher temperature within the valley is indicative of a warmer local climate. Especially at night-time, these temperature differences are pronounced. Also, the valley is more or less sheltered from the large-scale katabatic winds, as shown by the lower mean surface wind speed at site 3 which is in the centre of the valley away from gustiness next to the rock wall.

Comparing these values with measurements of January 1988 (Jonsson, 1992), we should note that the 1992-93 temperatures are $3.5^{\circ} \mathrm{C}$ lower, relative humidity 


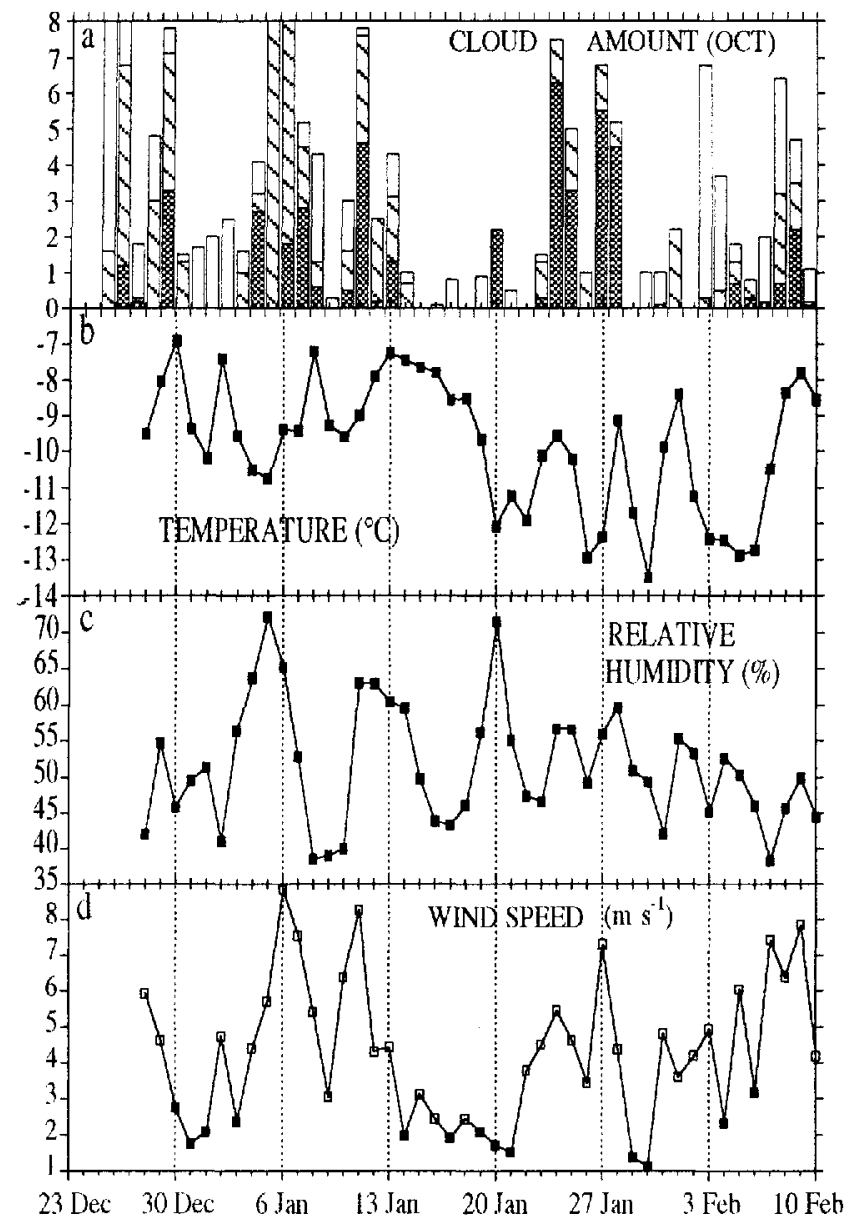

Fig. 2. Daily azeraged values of $(a)$ cloud amount, $(b)$ temperature, (c) relatice humidity and (d) wind speed, measured at sile 3. In (a), low clouds are indicaled by dark gray areas, middle clouds by hatched areas and high clouds by white areas. In (d), days with predominantly easterly winds are indicated by white dots while days with westerly winds are indicated by black dots.

is $5 \%$ lowcr and wind specds are $0.5 \mathrm{~ms}^{-1}$ higher. This is indicative of the inter-annual variability of the summerlime weather characteristics in this region. 'This was also noted by Jonsson (1992), who compared inter-annual variations in weather conditions, ablation rates and melt phenomena.

\section{SURFACE-ENERGY BALANCE}

The surface-cnergy balance over Antarctic snow surfaces has been extensivcly studied, c.g. Weller (1980), Carroll (1982) and Wendler and others (1988). However, the energy balance of blue-ice areas is relatively unknown. Fujii and Kusunoki (1982) attempted to relate calculated blue-ice sublimation rates to measured values but treated only the latent-hcat flux.

We will evaluate the total surface-energy balance both on bluc ice (site 2) and snow (sites 3 and 5). The differences between valley and plateau should follow from a comparison of sites 5 and 3 . The period 1 January-10 February 1993 (4l d) was used.

The surface-energy-balance equation can generally be written as (fluxes towards the surface are positive):

$$
S+L+H+L E+G=0
$$

where $S$ is net short-wave radiative flux, $L$ is net longwave radiative flux, $H$ is turbulent sensible-heat flux, $L E$ is turbulent latent-heat flux and $G$ is energy flux in snow or ice (heat conduction and penetrating short-wave radiation). Since we did not directly measure all components of Equation (1), we employed a simple model to evaluate the energy balance (Knap, 1992). The net short-wave radiation and the incoming part of the net long-wave radiation $L^{\downarrow}$ are taken from the measurements. The outgoing long-wave radiation $L^{\dagger}$ is calculated from the surface temperature $T_{\mathrm{s}}$ with $L^{\dagger}=\sigma T_{3}{ }^{4}$ in which the surface emissivity is assumed to equal unity. The turbulent fluxes $H$ and $L E$ are calculated using the Monin Obhukov similarity theory with stability corrections from Dyer (1974) and Duynkerke (1991). In the surface layer, the fluxes are assumed to be constant with height. The flux-profile relationships can then be intcgratcd analytically between two heights. However, by applying two heights in the atmosphere, this procedure yields unrealistically large fluxes on some occasions. Errors in the potential temperature gradient

7able 1. Mean and extreme meteorological data for the period 28 December 199210 February 1993, evaluated from hourly mean values

\begin{tabular}{|c|c|c|c|c|c|c|c|c|c|}
\hline \multirow[t]{3}{*}{ Site } & \multirow{3}{*}{$\begin{array}{c}\text { Surface elevation } \\
\text { ma.s.l. }\end{array}$} & \multicolumn{3}{|c|}{ Temperature $(2 \mathrm{~m})$} & \multicolumn{3}{|c|}{ Relalize humidity $(2 \mathrm{~m})$} & \multicolumn{2}{|c|}{ Wind speed $(6 \mathrm{~m})$} \\
\hline & & \multicolumn{3}{|c|}{${ }^{\circ} \mathrm{C}$} & \multicolumn{3}{|c|}{$\%$} & \multicolumn{2}{|c|}{$\mathrm{ms}^{-1}$} \\
\hline & & Min. & Mean & Max. & Min. & Mean & Max. & Mean & Max. \\
\hline 2 & 1170 & -17.1 & -8.3 & -1.9 & 24.3 & 51.5 & 81.4 & 4.9 & 15.9 \\
\hline 3 & 1250 & -17.8 & 9.8 & -3.3 & 26.9 & 51.6 & 88.0 & 4.2 & 11.5 \\
\hline 4 & 1200 & -20.1 & -10.8 & -2.0 & & & & 5.2 & 13.7 \\
\hline 5 & 1150 & -21.6 & -11.4 & 2.0 & & & & 5.8 & 14.3 \\
\hline
\end{tabular}


of $0.3-0.5^{\circ} \mathrm{C}$ can lcad to uncertainties in the sensible-heat flux of $100 \mathrm{Wm}^{2}$ or more under unstable conditions, due to the importance of convective turbulence. Since mcasurcd temperature gradients could be in error by up to $0.4 \mathrm{C}$, it was decided to use surfacc valucs (zcro wind speed, calculatcd surface temperature and specific humidity calculated using the surface temperature, assuming saturation) and onc lcvel in the atmosphere to calculate the turbulcnt fluxes. Then, surface-roughness lengths for momentum $\left(z_{0 \mathrm{~m}}\right)$, heat $\left(z_{0 \mathrm{~h}}\right)$ and moisture $\left(z_{0 q}\right.$ have to be used. Values of $z_{0 \mathrm{~m}}$ can easily be estimated from the assumption of a logarithmic windspeed profile under adiabatic conditions $\left(\left|z / L_{\text {mo }}\right| \leq 0.03\right.$ at $2 \mathrm{~m}$ with $L_{\mathrm{mo}}$ the Monin-Obhukov length) and are listed in Table 2. Obviously, $z_{0 m}$ increases going from smooth ice (site 2) via rclativcly smooth snow (site 3) to more irregular snow surfaces (sites 4 and 5 ). We assume that $z_{0 h}$ and $z_{0 q}$ are equal to $z_{0 m}$. Snow/ice temperatures in the top $80 \mathrm{~cm}$ are calculated using the well-known thermodynamic equation:

$$
\rho c_{\mathrm{p}} \frac{\partial T}{\partial t}=\frac{\partial}{\partial z}\left(K \frac{\partial T}{\partial z}\right)+\frac{\partial S(z)}{\partial z}
$$

where $\rho$ is measured density of snow $\left(400 \mathrm{~kg} \mathrm{~m}^{-3}\right)$ or ice $\left.850 \mathrm{~kg} \mathrm{~m}^{-3}\right), c_{\mathrm{p}}$ is specific-heat capacity at constant pressure $\left.2 \times 10^{3} \mathrm{~J} \mathrm{~kg}^{-1} \mathrm{~K}^{-1}\right), K$ is conductivity of snow $\left(0.3 \mathrm{~W} \mathrm{~m}^{-1} \mathrm{~K}^{-}\right.$ ${ }^{1}$ ) or ice $\left(5.2 \mathrm{Wm}^{1} \mathrm{~K}^{1}\right), S(z)$ is penetrated short-wave radiation at depth $z$ and $z$ is the coordinate normal to the surface. 'l'he first term on the righthand side represents molecular diffusion as well as convective processes (in snow). The last term of the righthand side of Equation (2) represents the amount of absorbed short-wave radiation. This amount decreases exponentially with depth, with cxtinction cocfficicnts $1.3 \mathrm{~m}^{1}$ (ice) and $20 \mathrm{~m}^{1}$ (snow) (Greuell and Oerlemans, 1989). From an initial snow/ice
Table 2. Values of the surface-roughness length for momentum $\left(z_{0 \mathrm{~m}}\right)$, calculated from wind-speed profiles under adiabalic condilions

\begin{tabular}{cc} 
Site & $\begin{array}{c}z_{0 \mathrm{~m}} \\
\mathrm{~mm}\end{array}$ \\
& \\
\hline 2 & 0.007 \\
3 & 0.084 \\
4 & 0.550 \\
5 & 0.750
\end{tabular}

tcmperature profile and input from hourly mean measured values of $S, L^{\downarrow}$, wind speed (2m), temperature $(0.8 \mathrm{~m})$ and specific humidity $(0.8 \mathrm{~m})$, the model calculates the surfaceheat fluxes. Then, from the surface-energy balance (Equation (1) and assumption of constant conductive flux at $0.8 \mathrm{~m}$, a new snow/ice temperature profile is calculated. Eventually, the surface-heat fluxes and snow/ice temperature protiles for a given period are evaluated using this iterative procedure. Obviously, the surface temperature is the most important variable to be solved, since it determines all heat fluxes except $S$ and $L^{\downarrow}$.

For calculating the energy balance at site 5, initial snow temperature, incoming long-wave radiation and relative humidity are taken from site 3 . An increase in relative humidity of $7.5 \%$ going from site 3 to site 5 is assumed (Jonsson, 1992).

The calculated and measured snow temperatures at site 3 compare well, given uncertainties in the measure-

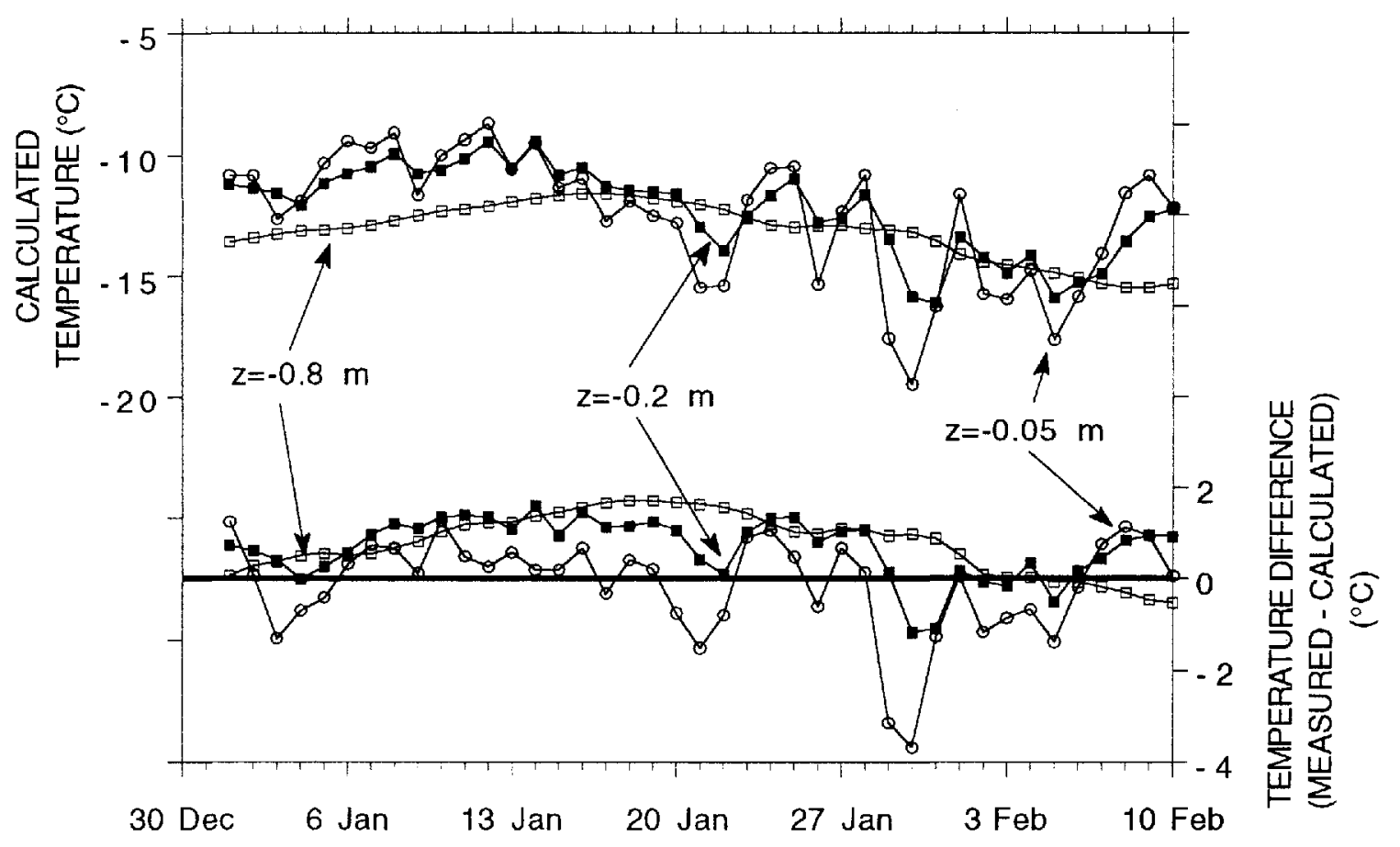

Fig. 3. Calculated daily mean snow temperatures and difference between measured and calculated snow temperatures at three depths at site 3. 


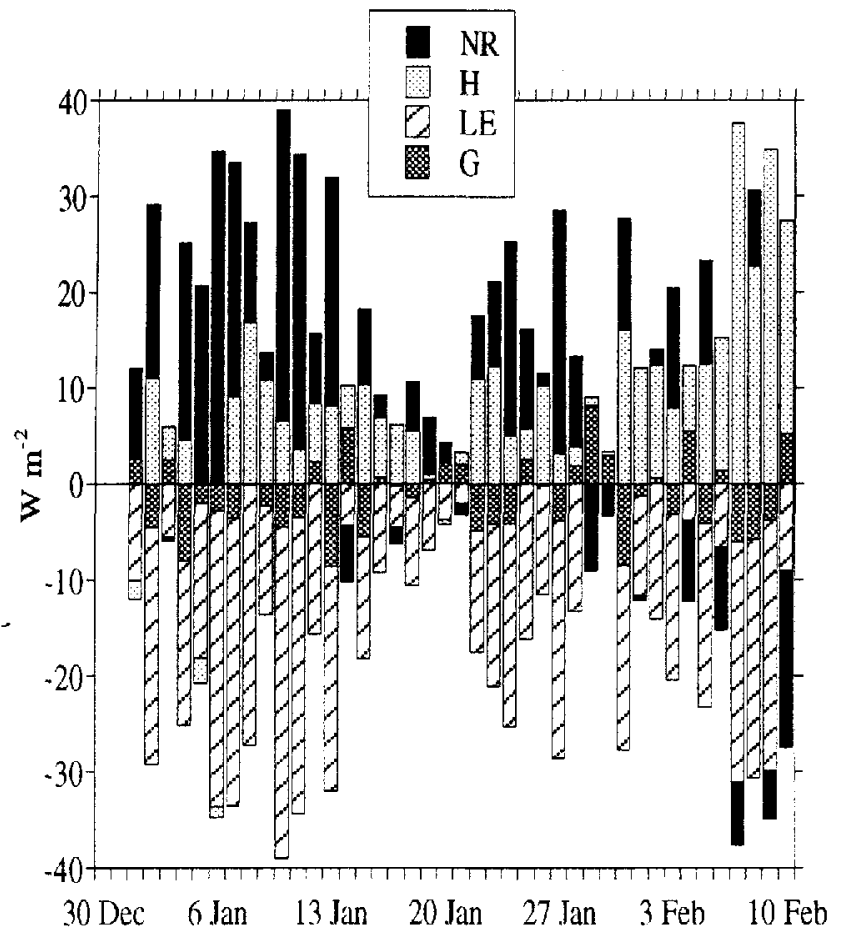

Fig. 4. Daily averaged values of the surface energybalance components at site 3. $N R$ is net radiation $(N R=$ $S+L)$. Fluxes towards the surface are positive.

ments and calculations (Fig. 3). The calculated daily mean temperatures at all depths do not differ by more than $2^{\circ} \mathrm{C}$ from the measurcd ones, except for $2 \mathrm{~d}$ at $5 \mathrm{~cm}$ depth. This good agreement means that we may have some confidence in the modeled surface-heat fluxcs.

Figure 4 shows the daily mean surface-heat fluxes at site 3 . The net radiation and sensible-heat fluxes are the two main heating terms, whilc encrgy is lost through sublimation and warming of the snow. Comparing the net radiation with cloudiness observations (Fig. 2), onc can see an increasing nct radiation with increasing cloudiness. This phenomenon is known as the radiation paradox and is typical for highly reflecting surfaces (Wendler and others, 1988). Generally, we may state that, in the presence of clouds in combination with high wind speeds (depression activity), large surface fluxes occur whereas in

Table 3. Mean surface-energy fluxes and mean albedo for the period I January 1992-10 February 1993. Fluxes towards the surface are positive. Symbols are explained in the text

Site 2

Site 3

63.7

$-56.0$

8.7

$H$

$L E$

$-80.7$

$-1.0$

$G$

$$
-23.9
$$

Albedo
$-15.1$

1.2

0.81
Site 5

63.1

58.6

18.5

$-22.1$

$-1.0$

0.80

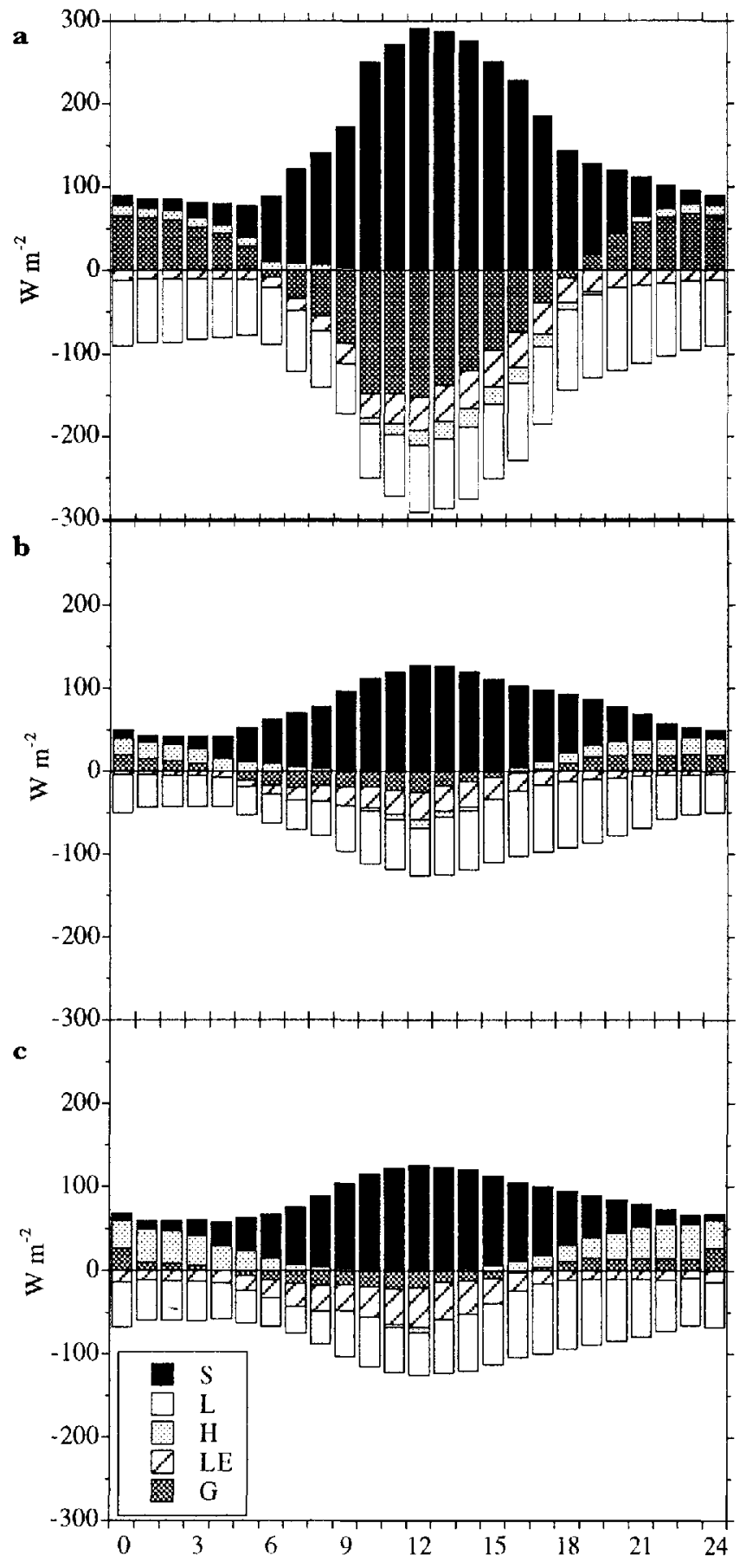

Fig. 5. Mean dailv cycle of the surface-heat fluxes at (a) site 2, (b) sile 3 and (c) site 5 for the period 1 January 10 February 1993. Fituxes towards the surface are positive.

the casc of fair weather and light winds the surface fluxes are very small.

The average diurnal cycle in the surface-heat fluxes at sites 2, 3 and 5 is depicted in Figure 5. The main difference between ice and snow surfaces is the net shortwave radiation caused by the albedo difference (Table 3 ). Over ice, the heat is mainly used to warm the ice during daytime but, over snow, energy is mainly lost by the latent-heat flux and net long-wave radiation. The warming of the ice is very effective through a large penetration depth for short-wave radiation and strong diffusion (large conductivity $K$ ). The larger surface heating causes a longer period of unstable stratification 
indicated by a negative sensible-heat flux. At night-time, cooling of the air over the ice is counteracted by the large upward heat flux in the ice, keeping the surface temperature relatively high. The main difference between sites 3 and 5 is the greater turbulent fluxes at sitc 5 , caused by the greater wind speeds and greater surfaceroughness values.

In Table 3 , the mean values over the measuring period are shown. In contrast to snow-covered areas, on blue-ice areas the sensible-heat flux is very small. The latent-heat flux is highest at site 2, where the largest sublimation rate was expected. However, only $78 \%$ of the ablation measured at a nearby stake $\left(0.94 \mathrm{~mm}\right.$ w.e. $\left.\mathrm{d}^{-1}\right)$ can be explained by this latent-heat flux. The latent-heat flux is smaller over snow, as expected. However, the sublimation rates over snow are still considerable, especially at site 5 . In general, the surface-energy fluxes over snow compare well qualitatively with results of Nindler and others (1988). Since sublimation rates in and around a blue-ice area do not seem to vary much, this suggests that the dominant process determining the formation and maintenance of blue-ice areas is the divergence of drifting snow.

The value of the latent-heat flux at site 5 should be interpreted with caution, because a constant relativehumidity difference between sites 3 and 5 is assumed. Assuming this difference is $12.5 \%$ instead of $7.5 \%$, the latent-heat flux decreases by $2.6 \mathrm{~W} \mathrm{~m}^{-2}$ accompanied by small changes in $H, L$ and $G$. Furthermore, the assumption of equal surface-roughness values probably yields an overestimation of the fluxes at site 5. As stated by Beljaars and Holtslag (1991), an interfacial sub-layer exists near the surface where the scalar-transfer processes are dominated by diffusion. In the case of aerodynamically rough flow, momentum is transferred to the surface by pressure forces on the roughness elements. Then, the heat- and moisture-roughness lengths will probably be considerably smaller than $z_{0 \mathrm{~m}}$ (Brutsaert, 1982). In the case of laminar flow $\left(z_{0 \mathrm{n}}\right.$ in the order of the diffusionroughness length $\nu / u_{*} \approx 10^{\overline{3}} \mathrm{~m}$, with $\nu$ the molecular diffusion coefficient for momentum and $u_{*}$ the friction velocity), the momentum exchange will be determined by diffusion. It is clear that at site 5 aerodynamically rough flow exists, in contrast to sites 2 and 3 . As a result, the absolute value of the turbulent fluxes at site 5 would decrease by $4.3 \mathrm{~W} \mathrm{~m}^{-2}$ if $z_{0 \mathrm{~h}}$ and $z_{0 \mathrm{k}}$ are assumed to be one order of magnitude smaller than $z_{0 \mathrm{~m}}$. However, even then the latent-heat llux is of the same order as at site 3 .

\section{LOCAL CIRGULATION}

The continental-scale Antarctic katabatic winds are famous for their persistence and, especially near the coast, their strength. The strength of the Antarctic continental-scale katabatic winds depends on the magnitude of the terrane slope and the temperature deficit of the boundary layer compared to the free atmosphere. In summer, the temperature deficit will be largest during the night and smallest during daytime, when heating of the surface partially or totally removes the surface-temperature inversion. In regions sufficiently close to the coast, like Heimefrontfjella, the synoptic pressure gradient is another important factor determining the strength of the flow. Finally, the permanently warmer coastal environment will lead to a cross-slope thermal wind, as proposed by Kodama and others (1989). During earlier measurements, the predominant surface-wind direction outside Scharffenbergbotnen was easterly (Jonsson, 1992), dirccted $50^{\circ}$ to the left of the fall line (which is oriented in a southcast-northwest direction).

A period of $42 \mathrm{~d}$ (31 December 1992-10 February 1993 ) was studied. Some mean characteristics of the surfacc wind outside the valley (site 5 ) are given in Figure 6 . The wind speed shows a double maximum at 0400 and 1400 GMT and the wind direction swings from $095^{\circ}$ at night towards $050^{\circ}$ in the afternoon. The surfacc-wind direction (Fig. 6b) is strongly related to the bulk Richardson number ( $\mathrm{Ri}_{\mathrm{b}}$ ) (Fig. 6d) that we introduce as a measure of stability of the surface layer:

$$
\mathrm{Ri}_{\mathrm{b}}=\frac{g \Delta \overline{\theta_{\nu}} \Delta z}{\overline{\theta_{\nu}}\left[(\Delta \bar{u})^{2}+(\Delta \bar{\nu})^{2}\right]}
$$

where $u$ and $\nu$ are the zonal and meridional components of wind, $g$ is the acceleration of gravity, $z$ is the height above the surface and $\theta_{\nu}$ is the virtual potential temperature. Differences in temperature and wind speed are taken between 2 and $6 \mathrm{~m}$. At night, when the surface layer is very stably stratified (large $R_{i}$, ), the katabatic or down-slope forcing increases, leading to strong surface winds balanced by down-slope forcing, Coriolis forcing and frictional forces. When the surfaceenergy balance becomes positive at $0600 \mathrm{GMT}$, the stability decreases rapidly and the boundary layer becomes unstably stratified at 1000 GMT. The surfacelayer air is mixed vertically and the surface winds will be directed along the upper-air geostrophic flow. In the absence of a synoptic pressure gradient and katabatic forcing, the cross-slope flow is entirely due to the mesoscale horizontal temper-ature gradient between the ice cap and the coastal environment (Fig. 6a). This mechanism of daily var-iation of the boundary layer on undisturbed Antarctic slopes in summer was first proposed by Kodama and others (1989) based on measurements in Terre Adélie, and is confirmed by our measurements outside the valley.

The build-up of a high-pressure ridge in the Weddell Sea will cause lulls in the katabatic winds, e.g. in the period 14-21 January (Fig. 2). During these periods, the. surface wind within the valley becomes wcak and mostly westerly during daytime, indicating the development of a local circulation. Moreover, during the short night, the generally light wind speeds will enhance strong cooling of the sloping surface, inducing shallow katabatic flow at all measuring sites: cold air, with a typical vertical cxtent of only $10-20 \mathrm{~m}$, streams along the local fall-line into the depression of the vallcy and stagnates there. If the local slope does not coincide with the regional fall-line, as is the case for the masts near and within the depression, the formation of these shallow flows will dramatically decrease the surface-directional constancy (defined as the ratio of vector mean wind speed and absolute mean wind speed). 

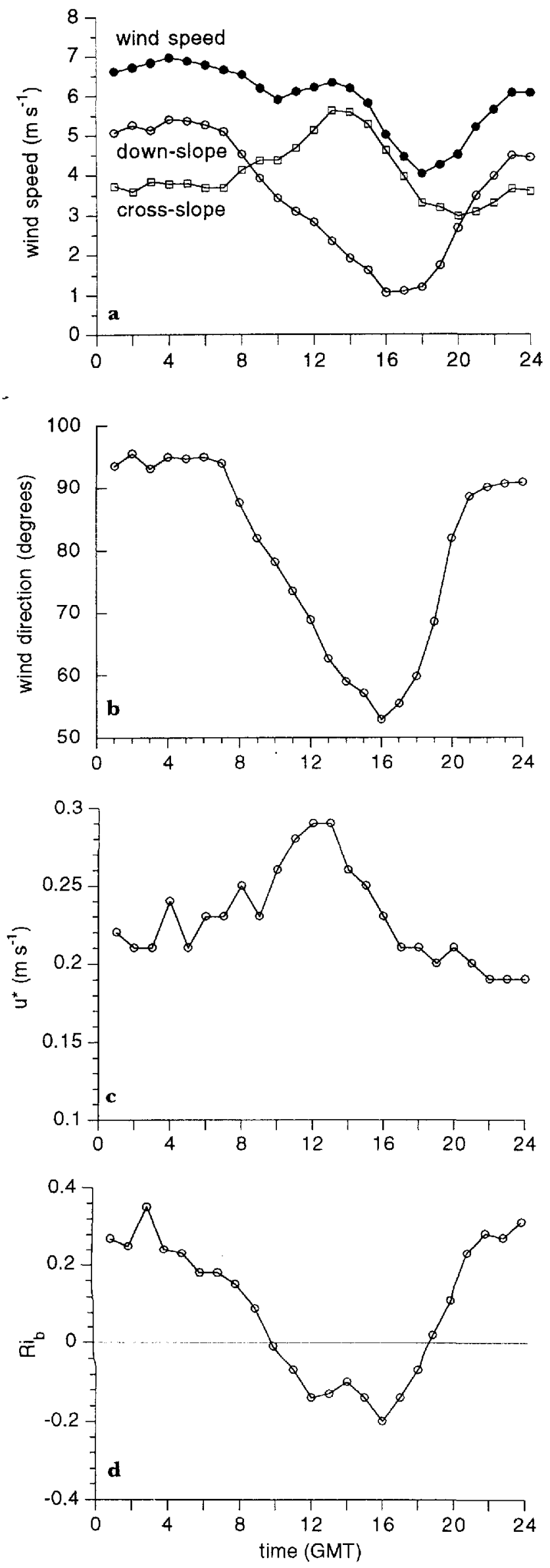

Fig. 6. Mean daily gicle for the period 31 December 199210 February 1993 of (a) wind speed, cross- and down-slope components, (b) wind direction, (c) friction velocity and (d) bulk Richardson number for site 5 outside the valley.
Table 4. Mean surface-wind speed $(6 \mathrm{~m})$, directional constancy $(6 \mathrm{~m})$ and friction velocity $(2-6 \mathrm{~m})$ at four sites for days without local circulation (lype 1) and days with local circulation (type 2)

\begin{tabular}{lcccccc} 
Site Wind speed $(6 \mathrm{~m})$ & $\begin{array}{c}\text { Directional } \\
\text { constancy }\end{array}$ & Fricition ielocity \\
& Type 1 & Type 2 & Type 1 & Type 2 & Type 1 & Type 2 \\
\hline & & & & & & \\
2 & 6.9 & 2.4 & 0.80 & 0.09 & 0.14 & 0.04 \\
3 & 5.7 & 2.4 & 0.83 & 0.18 & 0.13 & 0.03 \\
4 & 6.9 & 3.1 & 0.90 & 0.71 & 0.26 & 0.09 \\
5 & 7.0 & 4.6 & 0.93 & 0.86 & 0.29 & 0.21 \\
& & & & & & \\
\hline
\end{tabular}

A distinction is made between days without (type 1) and days with (type 2) the formation of a local circulation. Both types occurred about equally frequently (23 and $19 \mathrm{~d}$, respectively). Table 4 clearly shows that, especially within the valley, the mean wind speed, friction velocity and directional constancy near the surface are much lower during days with a local circulation.

Since the surface wind in the valley is strongly influenced by these shallow flows, the structure of the local circulation can best be studied using vertical soundings. Time-height cross-sections of mean crossslope (northeast-southwest) wind speed and directional constancy at Svea are given in Figure 7, averaged for a $6 \mathrm{~d}$ period with small synoptic forcing (14-19 January 1993) when regular soundings were carried out (every $3 \mathrm{~h}$ ). No regular variation could be detected in the down-slope (southeast-northwest) component (Fig. 1), which is not shown here (note that with "down-slope" the regional slope is meant instead of the local slope of the terrane).

Figure 7a shows that, on days with a local circulation, westerly winds are present near the surface, whereas above $400 \mathrm{~m}$ casterly winds persist throughout the day. These surface westerlies did not occur outside the valley at site 5 . In the afternoon, during adiabatic conditions, the upper air circulation quickly penetrates towards the surface in the valley. Figure $7 b$ clearly demonstrates the semi-permanent fcatures of mesoscale forcing of the casterly winds during the day and the slope-dependency of the shallow katabatic winds at night (high directional constancy). The weak westerly local winds are characterizcd by low directional constancy.

\section{CONCLUDING REMARKS}

Results are presented from measurements carried out in the period Decomber 1992-February 1993 in Heimefrontfjella, Dronning Maud Land, East Antarctica. Detailcd meteorological measurements were carried out in the immediate vicinity of a blue-ice area, on ice as well as on snow. Mean temperatures during the 7 week 


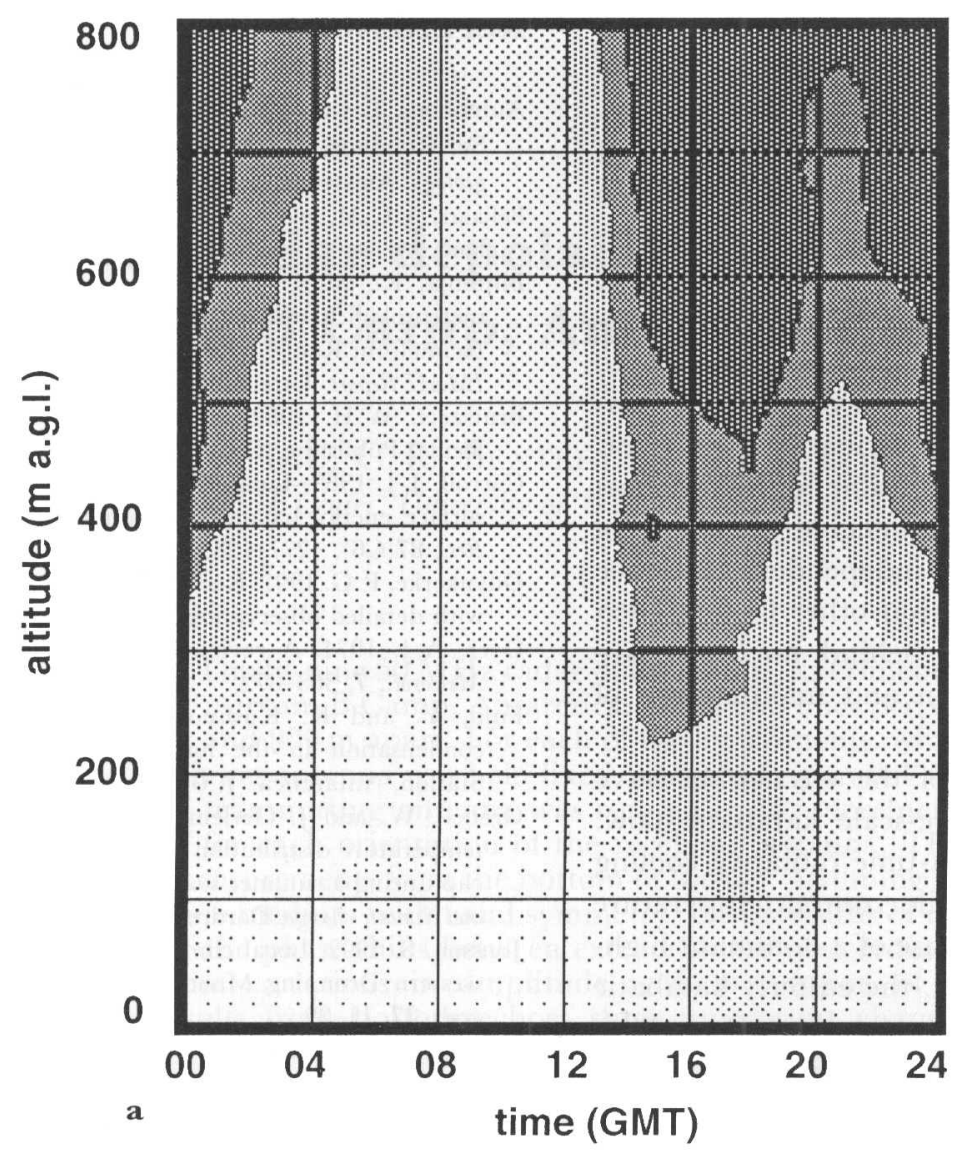

\section{cross slope wind $(\mathrm{m} / \mathrm{s})$}
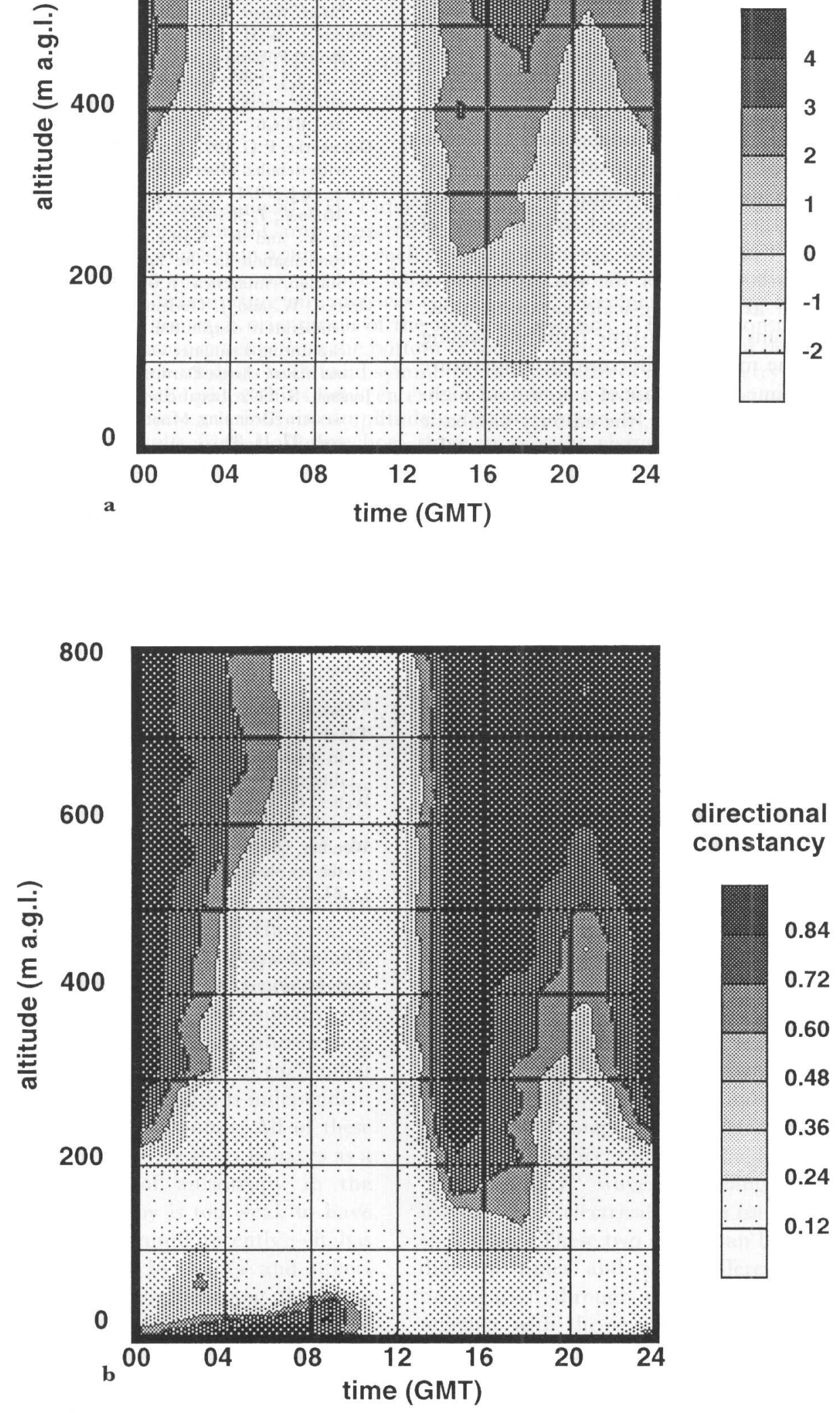

Fig. 7. Mean time-height cross-section of (a) cross-slope (northeast-southwest) wind componenl and (b) winddirectional constancy at the base camp for a $6 \mathrm{~d}$ period (14-19 January) in which a local circulation developed. 
measuring period ranged from $-8.3^{\circ} \mathrm{C}$ at site 2 to $-11.4^{\circ} \mathrm{C}$ at site 5 , indicating the warm local climate within the valley where the blue-ice field is located. The surfaceencrgy balance is evaluatcd using a simple model and measured meteorological parameters. The differences in the surface-energy balance between snow and ice (larger net short-wave radiation accompanied by larger negative contributions of net long-wave radiation, turbulent fluxes and conductive flux) can be attributed mainly to differences in albedo, surface roughness, thermal conductivity and short-wave radiation extinction cocfficient. The latent-heat flux, which is responsible for loss of mass and therefore one of the factors influencing the extent of the blue-ice ficld, sccms to be fairly independent of surface -type. We can therefore conclude that other factors, such as reduced snowdrift divergence behind nunataks, are more important for the formation and maintenance of blue-ice areas.

Some typical characteristics of the circulation have been described, such as the large-scale katabatic flow. The forcing mechanisms are night-time radiative cooling at the surface and the mesoscale horizontal temperature gradient during daytime. In the case of a dominant highpressure ridge in the Weddell Sea, the easterly katabatic wind is replaced by westerly winds near the surface. This local circulation leads to lower wind speeds in the valley and hence lower turbulent exchange sec Table 4 and Figure 5). The local circulation therefore limits the sublimation rate within the valley.

\section{ACKNOWLEDGEMENTS}

We should like to thank the Swedish and Norwegian cxpcdition members for thcir help and support during the expedition. We are grateful to P. Duynkerke, W. Knap and J. Oerlemans for advice and discussions. $M$. Portanger is acknowledged for technical and electronic assistance. Financial support was provided by the Netherlands Organization for Scientific Research (NWO), the Dutch National Research Programme on Global Air Pollution and Climate Change (NOP), and the Netherlands Marine Research Foundation (SO7.).

\section{REFERENCES}

Autenboer, T. van. 1964. The geomorphology and glacial geology of the Sor-Rondane, Dronning Maud Land. In Adic, R.J.ed. Autartic geolugy. Amsterdam, North-Holland Publishing Co., 81103.

Beljaars, A.C.M. and A. A. M. Holtslag. 1991. Flux parameterization over land surfaces for atmospheric models. 7. Appl. Meterol., 30, 327-311.

Bintanja, R., M.R. van den Broeke and M. P. Portanger. 1993. A meteorological and glaciological experiment on a blue ice area in the Hcimefront Range, Queen Maud Land. Antarctica. Sire Field Repont. IMAU Report. Utrecht, Utrecht University.

Brutsaert, W.H. 1982. Euaporation int the atmosphese. Dordrecht. Г). Rcidd Publishing Co.

Carroll, J.J. 1982. Long-term means and short-term variability of the surface energy balance components at the South Pole. 7. Genphrs. Res., 87(C6), 4277-4286.

Duynkerke, P. G. 1991. Radiation log: a comparison of model simulation with detailed observations, Mon. Weath. Rer., 119, 324341

Dyer, A.J. 1974. A review of flux-profile relationships. Bound. Laner Meteorol., 7, 363-372.

Fujii, Y, and K. Kusunoki. 1982. The role of sublimation and condensation in the formation of ice sheet surface at Mizuho Station, Antarctica. 7. Geophys. Res, 87 (C6), 4293-4300.

Greuell, W. and J. Oerlemans. 1989. The evolution of the englacial temperature distribution in the superimposed ice zone of a polar ice cap during a summer scason. In Orrlemans, J., ed. Glacier fluchations and climatic change. Dordrecht, Kluwer Academic Publishers, 289-303.

Jonsson, $\$$. 1992. Local climate and mass balance of a blue-ice area in western Dronning Maud Land. Antarctica. Z Gletskerkd Ginzialgeol., 27, $11-29$.

Knap, W. H. 1992. A study on the albedo and energy balance of an alpine snow field in the winter season. IMAL Report, Utrecht. Utrecht University.

Kodarna, Y., G. Wendler and V. Ishikawa. 1989. The diurnal variation of the boundary layer in summer in Adelie Land, eastern Antarctici. 7. Appl. Meterrol., 28, 16-24.

Orheim. O and B. Lucchitla. 1990. Investigating climate change by digital analysis of blue ice extent on satellite images of Antarctica. Ann. Glaciol., 14, 211-215.

Schytt, V. 1961. Blue icc ficlds, moraine features and glacier fluctuations. Norwegian-British-Sitedish Antarctic Evpedition 1949-5z. Scientific Results, Vol. IV. E. Oslo, Norsk Polarinstitutt.

Takahashi, S., R. Narusc, M. Nakawo and S. Mac. 1988. A bare ice ficld in cast Queen Maud Land, Antarctica, caused by horizontal divergence of drifting snow. Ann. Glaciol., 11. 156160.

Weller, G. 1980. Spatial and temporal rariations in the South Polar surface energy balance, Mon. Healh. Rez', 108, 2006-2014.

Wendler, G., N. Ishikawa and Y. Kodama. 1988. The heat balance of the icy slope of Adclie Land, castorn Antarctica. 7 . Appl. . Weterol.. 27, $52-65$

The accuracy of references in the lext and in this list is the responsibility of the authors, to whom queries should be addressid. 